\title{
Uranium (VI) Removal from Flood Water Using Trioctyl Amine (TOA), At Abu Rusheid Area, South Eastern Desert, Egypt.
}

\author{
L.A Yousef and G.M.Saleh \\ Nuclear Materials Authority, P.O.Box 530 El Maadi, Cairo, Egypt
}

\begin{abstract}
Flash floods are considered natural disasters that can cause casualties and demolishing of infrastructures. The flash flood takes place over Abu Rusheid in 29 November 2011. After one month from the falling of flood, ten flooding water samples were collected from the cavities in the mountain at Abu Rusheid area, South Eastern Desert, Egypt. The salinity ranges between 380 and 1460 ppm, while pH ranges between 7.1 and 8.1 .

Trioctyl amine (TOA) dissolved in kerosene has been chosen for removal both of uranium and thorium. Different parameters were carried out testing the following variables: different diluents, TOA concentrations, aqueous to organic phase ratio, shaking time, temperature, and different stripping agents. The factors studied were followed by application of the removal system to determine the uranium and thorium from flooding water samples.

The uranium concentration in the studied area were ranged between $172 \mathrm{ppb}$ and $1012 \mathrm{ppb}$. While, thorium was ranged between $98 \mathrm{ppb}$ and $524 \mathrm{ppb}$. Meanwhile, the dissolution and leaching (\%) of uranium and thorium in flood water samples after one month from the falling of flood in the studied area are ranging between 0.032 $0.9 \%$ and $0.016-0.36 \%$.

After chemical treatment of the flood water was observed that, the remaining elements of uranium and thorium are very few. We recommend not to use those waters from flooding which contain a small concentration of uranium.
\end{abstract}

Keywords: Flood Water, Abu Rusheid, U (VI) ,Th (IV), TOA, Leaching (\%).

\section{Introduction}

Abu Rusheid area is mostly crystalline basement rocks. The area is bounded between longitudes $34^{\circ} 46^{\prime}$ $02^{\prime \prime}$ and $34^{\circ} 46^{\prime} 15^{\prime \prime} \mathrm{E}$ and latitudes $24^{\circ} 37^{\prime} 35^{\prime \prime}$ and $24^{\circ} 37^{\prime} 51^{\prime \prime} \mathrm{N}$, at the south Eastern Desert of Egypt (Fig. 1). Ten flooding water samples were collected from Abu Rusheid area of study during winter season in 29 November 2011 (Table 1). This area is characterized by low topographic features. Abu Rusheid area is highly mineralized by secondary U- minerals (uranophane, kasolite, autunite and meta-autunite), REEs (up to $1.2 \%$ ), $\mathrm{Zn}$ (ranges from 1-3\%), $\mathrm{Cu}, \mathrm{Pb}$ and $\mathrm{Ag}[\mathbf{1}]$.

Flash flood events can cause severe damage and loss of life in arid and semi arid regions such as Eastern Desert area. Moreover, flash floods resist area development and lead to environmental negative impacts such as erosion and pollution. Flash floods forecasting is considered a difficult task, particularly in arid and semi arid zones, since they take place in very short time [2].

Hence, the forecasting of rainfall is very necessary for providing early warning before the presence of flash flood to avoid disasters [3]. Flooding is the main devasting in Egypt [4]. Previous records of floods were hit parts of Upper Egypt, Sinai, Red Sea and Eastern Desert areas for example from 1976 to 2010 [5].

The Egyptian Red Sea coastal zone and Eastern Desert are much targeted for oil industry, mining activities and tourism recreation. These developments and local economy are threated by natural flash floods. Climatic conditions in the area require an efficient tool to identify the environmental threats and rainfall [6-12].

The early warning system (EWS) for flash floods has been developed and faced limited availability of field data (rainfall and flash floods events). It must be suggested the essential parameters to identify the data conditions on area such as: information of past rainfall and flash floods events, temporal distribution of the rainfall events and the finally, transmission and infiltration losses [13-19].

Uranium and thorium are used extensively in nuclear energy programs; hence several methods were required for its separation and determination. Removal process is one of the most common and important methods for removal and purification of many elements and always proved itself very helpful as a recovery method for many components. Uranium (VI) was removed using different organic extractants such as trioctylphosphine oxide (TOPO) dissolved in cyclohexane $\left(\mathrm{C}_{6} \mathrm{H}_{12}\right)$ [20].

Di (2-ethylhexyl) phosphoric acid (DEHPA) diluted in carbon tetrachloride $\left(\mathrm{CCl}_{4}\right)$ was used for removal of U (VI) and determind by infrared spectroscopy [21]. Whereas tri (2-ethylhexyl) phosphate (TEHP) was used for removal of $\mathrm{U}$ (VI) [22]. Uranium was removed using tributylphosphine oxide (TBPO) diluted in toluene $\left(\mathrm{C}_{6} \mathrm{H}_{5} \mathrm{CH}_{3}\right)$, and determined by fluoride fusion method [23]. 
Many solvents containing amine group were applied to remove uranium as 8-hydroxylqunoline [24]. Meanwhile, uranium was recovered using $\left(\mathrm{R}_{3} \mathrm{PO}\right)$ cyanex-923 [25]. Selective separation of uranium and thorium was carried out using N-phenylbenzo-18-crown-6-hydroxamic acid (PBCHA) [26, 27]. Removal of uranium (VI) by di-2,4,4-trimethyl-bentyl phosphoric acid (cyanex - 272) dissolved in toluene [28] was reported. While, tributyl phosphate (TBP) was used for removal of U (VI) [29].

The main purpose of the work, studies the dissolution and leaching (\%) of U (VI) and Th (IV) from the cavities in Abu Rusheid mountain surface after one month from the falling of the flood, Abu Rusheid area, SED, Egypt.

\subsection{Instrumentations}

\section{Experimental}

Generally, the reagents used in this work were weighed using an electronic analytical balance of Shimadzu AY 220 (Germany). The colorimetric methods were determined by Metertech Inc model Sp-8001, with the range 200-1100 $\mathrm{nm}$ (Germany). One match of $5 \mathrm{~cm}^{3}$ quartz cell with a pass length of $1 \mathrm{~cm}$ was used for both samples and blank reagent [30]. Double distilled water was used for preparing all standard solutions and reagents using Aquatron $4 \mathrm{~L} / \mathrm{h}$ (England).

$\mathrm{eU}(\mathrm{ppm})$ and $\mathrm{eTh}(\mathrm{ppm})$ have been measured in the field using gamma ray multi- channel RS-230 spectrometer model BGO portable radiation detector, with high accuracy and its probable measurement errors was about $5 \%$.

\subsection{Chemicals used}

All chemicals and reagents used were of analytical grade (AR). Uranium stock solution was prepared by dissolving $2.109 \mathrm{~g}$ of $\mathrm{UO}_{2}\left(\mathrm{NO}_{3}\right)_{2} \cdot 6 \mathrm{H}_{2} \mathrm{O}$ with purity $>99.99 \%$ in a definite volume $1000 \mathrm{ml}$ double distilled water containing $2 \mathrm{ml}$ of $6 \mathrm{M} \mathrm{HNO}_{3}$ acid to get a fixed concentration of $1000 \mathrm{ppm}$. The different concentrations of uranium were prepared by dilution.

While, thorium stock solution was prepared by dissolving $2.38 \mathrm{~g}$ of $\mathrm{Th}\left(\mathrm{NO}_{3}\right)_{4} \cdot 4 \mathrm{H}_{2} \mathrm{O}$ dissolving in 1000 $\mathrm{ml}$ double distilled water containing $1 \mathrm{ml}$ concentrated nitric acid. Some radioactive elements include $\mathrm{U}$ and $\mathrm{Th}$ was also measured by Arsenazo-III as an indicator [31-33].

In the present study, several attempts have been made to remove and determine uranium and thorium using trioctyl amine (TOA) as organo- amine compound from nitric acid medium with chemical formula of $\mathrm{C}_{24} \mathrm{H}_{51} \mathrm{~N}$ and a molecular weight of $353.68 \mathrm{~g} / \mathrm{mol}$.

The success of TOA compared to other processes for purification of uranium and thorium is due to it's highly selectivity for uranium and provide excellent decontamination from most impurities. It was used for removal both elements from different concentrations from low grade to high concentrations [34-37].

\section{Results and discussion}

Ten flood water samples were collected from Abu Rusheid area, south Eastern Desert of Egypt. The salinity ranges between 380 and $1460 \mathrm{ppm}$. The water alkalinity of the studied samples ranges between 7.1 and 8.1 , indicating slightly basic media Table (2).

\subsection{Factors affecting the removal of uranium (VI) and thorium (IV).}

The removal behavior of U(VI) and Th (IV) were carried out using trioctyl amine (TOA) diluted with different diluents. Several experiments were done to study factors controlling on the removal of them such as diluent types, TOA concentrations, aqueous to organic (A/O) phase ratio shaking time, temperature and different stripping agents.

Different concentrations from 0.02 to $0.2 \mathrm{M}$ of trioctyl amine (TOA) were prepared in appropriate diluents such as toluene $\left(\mathrm{C}_{6} \mathrm{H}_{5} \mathrm{CH}_{3}\right)$, kerosene $\left(\mathrm{C}_{12} \mathrm{H}_{26}\right)$, benzene $\left(\mathrm{C}_{6} \mathrm{H}_{6}\right)$, cyclohexane $\left(\mathrm{C}_{6} \mathrm{H}_{12}\right)$ or chloroform $\left(\mathrm{CHCl}_{3}\right)$.

\subsubsection{Effect of diluents.}

To choose which diluent is the best for uranium or thorium removal, (TOA) was dissolved in different diluents namely; toluene, benzene, kerosene, chloroform, or cyclohexane. This organic phase was shaked to the aqueous phase containing uranium or thorium solution at the ambient room temperature $\left(22 \pm 1^{\circ} \mathrm{C}\right)$.

From the experiments applied for checking the suitable diluent, it was found that, TOA in kerosene as a diluent gives high removal efficiency, more than $(96 \%)$ to remove uranium from solution if compared with benzene $(80.83 \%)$, cyclohexane $(77.5 \%)$, toluene $(73.33 \%)$ and chloroform (20\%) for one contact. It means that, the priority at which the removal increases is kerosene $>$ benzene $>$ cyclohexane $>$ toluene $>$ chloroform (Fig.2). 
On other hand, it was found that TOA in kerosene as a diluent gives high removal efficiency, more than $(95 \%)$ to remove thorium from solution if compared with benzene $(85 \%)$, cyclohexane $(80 \%)$, toluene $(75 \%)$ and chloroform (55\%) for one contact. It means that, the priority at which the removal increases is kerosene $>$ benzene $>$ cyclohexane $>$ toluene $>$ chloroform (Fig.2).

\subsubsection{Effect of (TOA) concentrations.}

Different concentrations from 0.02 to $0.2 \mathrm{M}$ of (TOA) in kerosene had been applied during the experiments run to study the removal (\%) of uranium or thorium. By changing the concentrations of TOA from 0.02 to $0.2 \mathrm{M}$, it was found that the removal (\%) of uranium reach its maximum removal $(99.5 \%)$ at $0.02 \mathrm{M}$ of TOA in kerosene. While, removal of thorium was done (97.5\%) at $0.04 \mathrm{M}$ (Fig.3).

\subsubsection{Effect of aqueous to organic phase ratio (A/O).}

The effect of aqueous phase (A) to organic phase (O) ratio on the removal of uranium or thorium was studied covering the range 1:1,2:1, 3:1, 1:2, and 1:3 while the other factors were kept constant. The obtained results indicated that the ratio 1:1 showed the best removal percentage $(99.5 \%)$ for uranium and $(97 \%)$ for thorium (Fig.4).

\subsubsection{Effect of shaking time.}

The effect of shaking time on the removal of U (VI) or Th (IV) was studied by varying the shaking time from 0.5 to 10 minutes using (TOA). It was found that the removal (\%) of uranium changes from $90 \%$ with 0.5 min. shaking time to $99.5 \%$ with 5 min. shaking time, then the removal (\%) were kept constant till 10 minutes. Therefore, the required shaking time to remove most uranium (VI) from its solution was chosen as 5 minutes.

On other hand, the removal (\%) changes from $88 \%$ with 0.5 min. shaking time to $97.5 \%$ with 4 min., then the removal (\%) were kept constant till 10 minutes. So that, the required shaking time to remove most Th (IV) was chosen as 4 minutes (Fig.5).

\subsubsection{Effect of temperature.}

The effect of temperature on the removal of U (VI) or Th (IV) was studied by varying the temperature from 22 to $100^{\circ} \mathrm{C}$. It was found that the removal (\%) of uranium changes from $99.5 \%$ with $22^{\circ} \mathrm{C}$ to $11 \%$ with $100^{\circ} \mathrm{C}$. Therefore, the required temperature to remove most uranium (VI) was chosen at ambient room temperature, $\left(22^{\circ} \mathrm{C}\right)$. While, the removal (\%) of thorium ranges from $97 \%$ with $22^{\circ} \mathrm{C}$ to $42 \%$ with $100^{\circ} \mathrm{C}$. So, the required temperature to remove most Th (IV) was $22^{\circ} \mathrm{C}$ (Fig.6).

\subsubsection{Effect of different stripping agents.}

Different stripping agents were tried for back removal of U (VI) or Th (IV) from the organic phase, the stripping was tested using certain stripping agents such as nitric, sulphuric, ortho-phosphoric and hydrochloric acid. The acids molarities ranged from 0.5 to $6 \mathrm{M}$.

It was found that $96,87,75$ and $65 \% \mathrm{U}$ can be stripped by $1 \mathrm{M} \mathrm{HNO}_{3}, 6 \mathrm{M} \mathrm{H}_{2} \mathrm{SO}_{4}, 6 \mathrm{M} \mathrm{H}_{3} \mathrm{PO}_{4}$ and $6 \mathrm{M}$ $\mathrm{HCl}$ acid, respectively. Accordingly, $1 \mathrm{M} \mathrm{HNO}_{3}$ acid was chosen as the best stripping solution for uranium (Fig.7).

While, $96,84,72$ and $68 \%$ Th can be stripped by $2 \mathrm{M} \mathrm{HNO}_{3}, 4 \mathrm{M} \mathrm{H}_{2} \mathrm{SO}_{4}, 6 \mathrm{M} \mathrm{H}_{3} \mathrm{PO}_{4}$ and $6 \mathrm{M} \mathrm{HCl}$ acid, respectively. Accordingly, $2 \mathrm{M} \mathrm{HNO}_{3}$ acid was chosen as the best stripping solution for thorium (Fig.8).

\subsection{Application for the removal method on uranium and thorium, Abu Rusheid area, South Eastern Desert, Egypt.}

Ten flood water samples were collected from Abu Rusheid area, south Eastern Desert, Egypt. In the present work, the removal of uranium (VI) was carried out by applying the previous factors controlling on uranium. Take $10 \mathrm{ml}$ of $100 \mathrm{ppb}$ uranyl nitrate solution was added to $10 \mathrm{ml}$ of $0.02 \mathrm{M}$ TOA dissolved in kerosene in a separating funnel according to $\mathrm{A} / \mathrm{O}$ ratio: $1 / 1$. The content of separating funnel was shaking according to $5 \mathrm{~min}$. at ambient room temperature $\left(22 \pm 1{ }^{\circ} \mathrm{C}\right)$. After that, the mixture was separated and the loaded uranium on TOA was stripped using $1 \mathrm{M} \mathrm{HNO}_{3}$ acid then determined spectrophotometrically by Arsenazo III method.

While, the removal of thorium (IV) was carried out by applying the previous factors controlling on thorium removal. By taking $10 \mathrm{ml}$ of $90 \mathrm{ppb}$ thorium nitrate solution was added to $10 \mathrm{ml}$ of $0.04 \mathrm{M}$ TOA dissolved in kerosene in a separating funnel according to $\mathrm{A} / \mathrm{O}$ ratio: $1 / 1$. The content of separating funnel was shaking according to $4 \mathrm{~min}$. at ambient room temperature $\left(22 \pm 1^{\circ} \mathrm{C}\right)$. After that, the mixture was separated, the thorium was stripped using $2 \mathrm{M} \mathrm{HNO}_{3}$ acid then determined spectrophotometrically by Arsenazo III method. 
The uranium concentration in the studied area indicated that, all water samples were ranged between $172 \mathrm{ppb}$ (sample No. 10) and $1012 \mathrm{ppb}$ (sample No. 1). Meanwhile, the concentration of uranium after stripping from TOA by $1 \mathrm{M} \mathrm{HNO}_{3}$ acid indicated that, all water samples were ranged between $171 \mathrm{ppb}$ (sample No. 10) and $1006.94 \mathrm{ppb}$ (sample No. 1) (Table 3).

While, thorium was ranged between 98 ppb (sample No. 3) and 524 ppb (sample No. 1). Meanwhile, the concentration of thorium after stripping from TOA by $2 \mathrm{M} \mathrm{HNO}_{3}$ acid indicated that, all water samples were ranged between $96 \mathrm{ppb}$ (sample No. 3) and $516 \mathrm{ppb}$ (sample No. 1) (Table 4).

The eU (ppm) and eTh (ppm) are ranging from 66 - $541 \mathrm{ppm}$ and 133- $1086 \mathrm{ppm}$ respectively (Tables 3 and 4). So, the dissolution and leaching (\%) of uranium and thorium in flood water samples after one month from the falling of flood in the studied area are ranging from $0.032-0.9 \%$ and $0.016-0.36 \%$ respectively.

\section{List of figures}

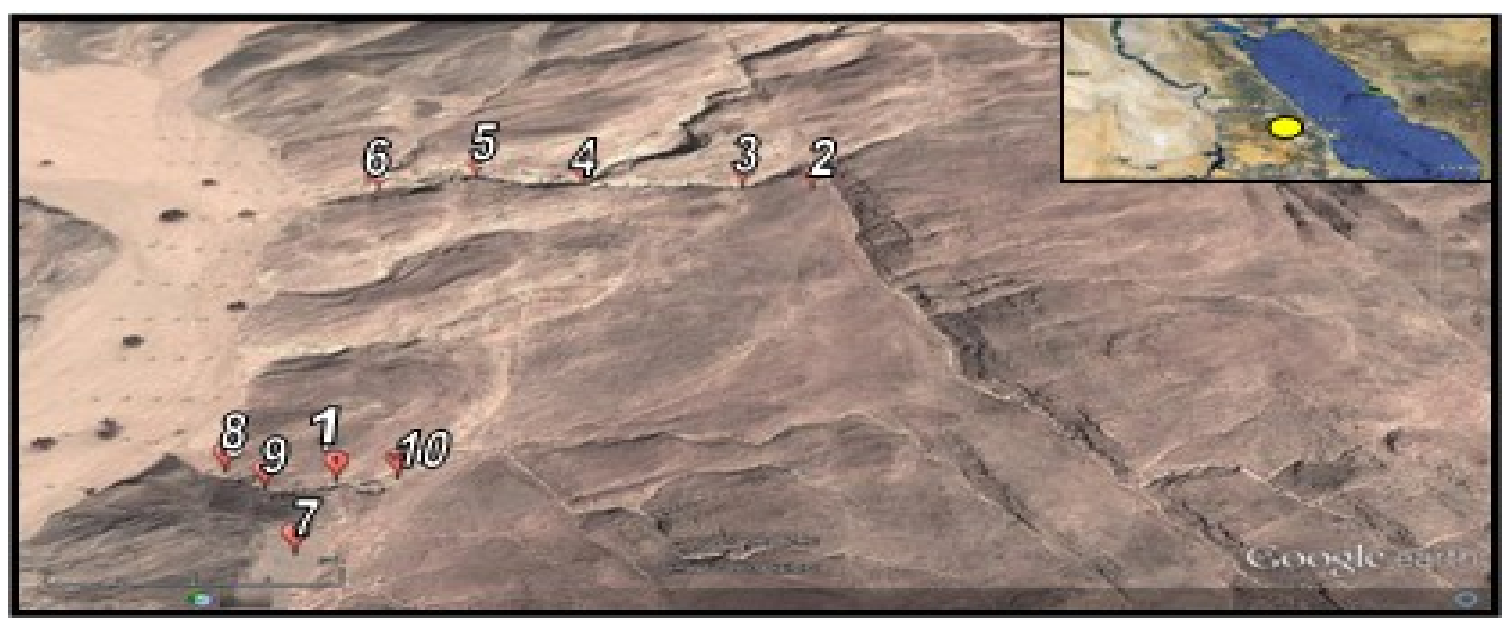

Fig.(1): Landsat location map of flood water samples selected from Abu Rusheid area, South Eastern Desert, Egypt.

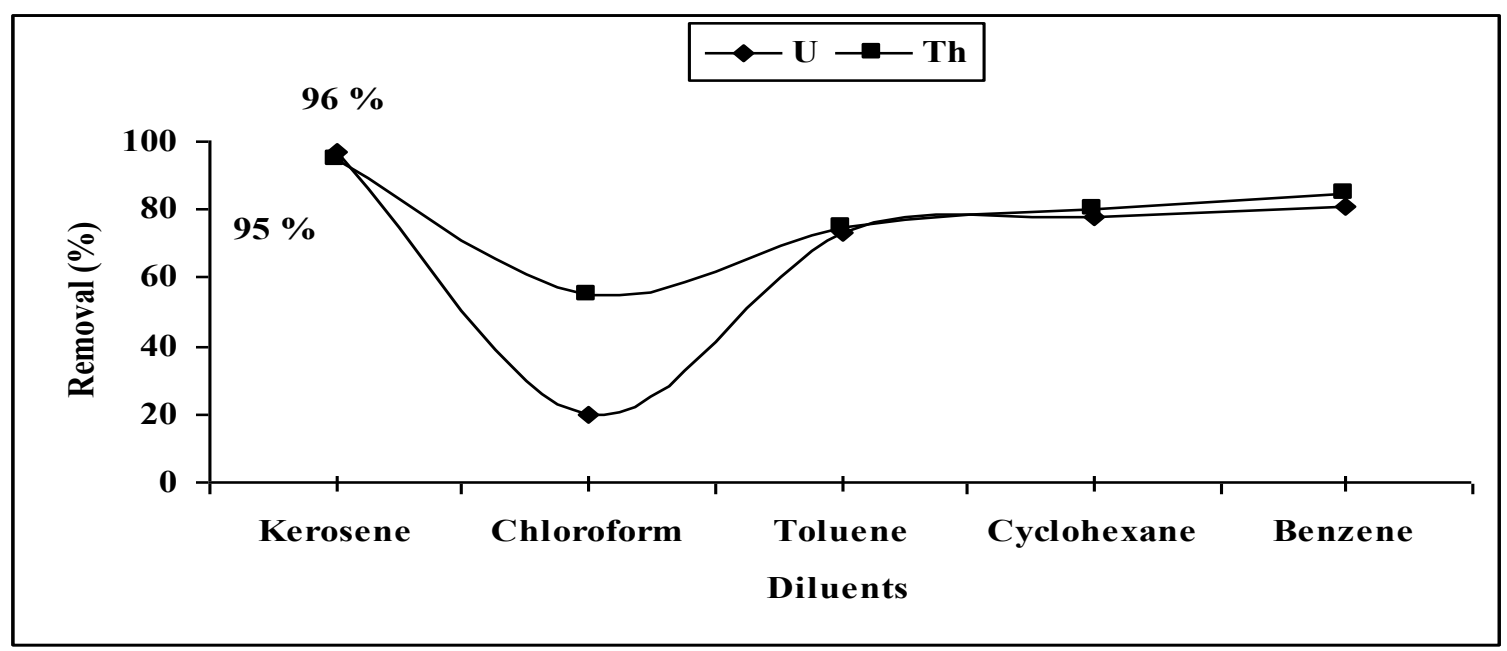

Removal conditions for uranium :

Uranium concentration : 100 ppb,0.02 M TOA dissolved in different diluents, $A / O: 1 / 1$, ambient room temperature and shaking time:5min.

Removal conditions for thorium :

Thorium concentration : $90 \mathrm{pp} b, 0.02 \mathrm{M}$ TOA dissolved in different diluents, $A / O: 1 / 1$, ambient room temperature and shaking time:5min.

Fig.(2): Effect of different diluents on uranium and thorium removal (\%). 


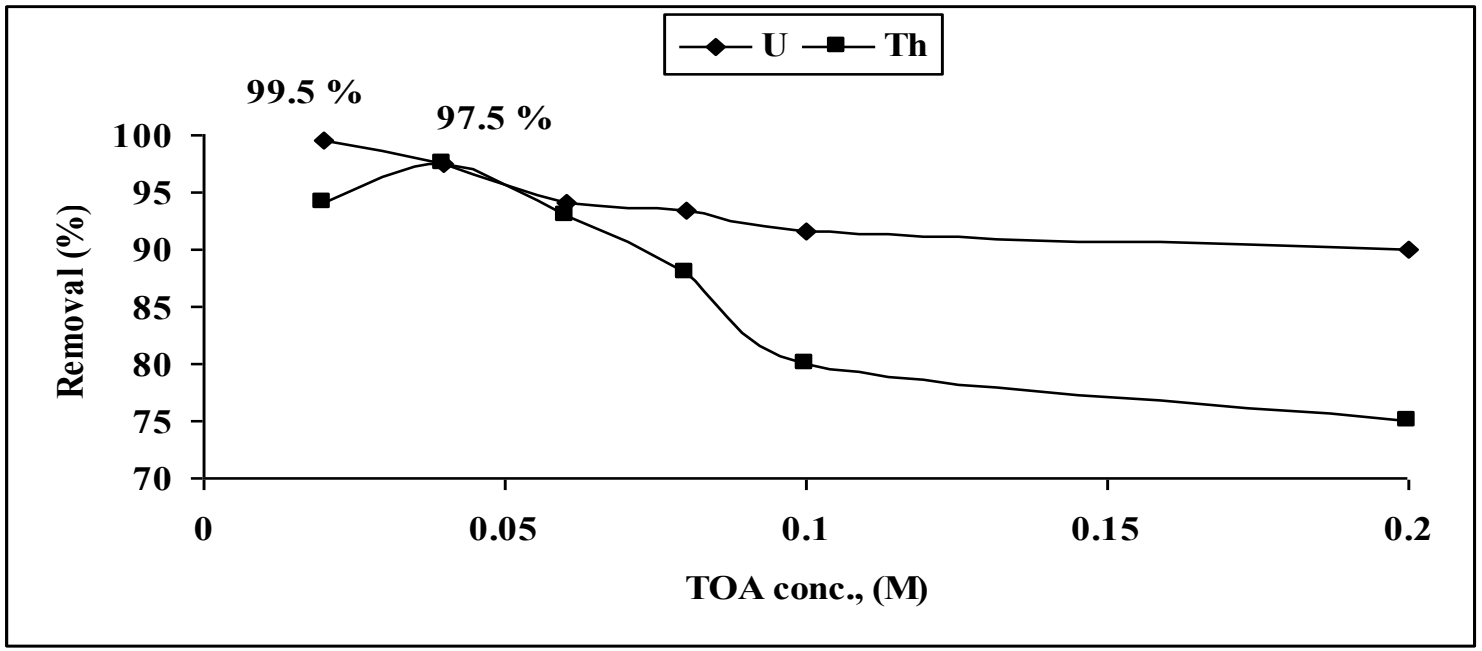

Removal conditions for uranium:

Uranium concentration : $100 \mathrm{ppb}$,

TOA dissolved in kerosene, A/O:1/1, ambient room temperature and shaking time:5min.

Removal conditions for thorium :

Thorium concentration : $90 \mathrm{ppb}$,

TOA dissolved in kerosene, A/O:1/1, ambient room temperature and shaking time:5min.

Fig.(3): Effect of TOA concentrations on uranium and thorium removal (\%).

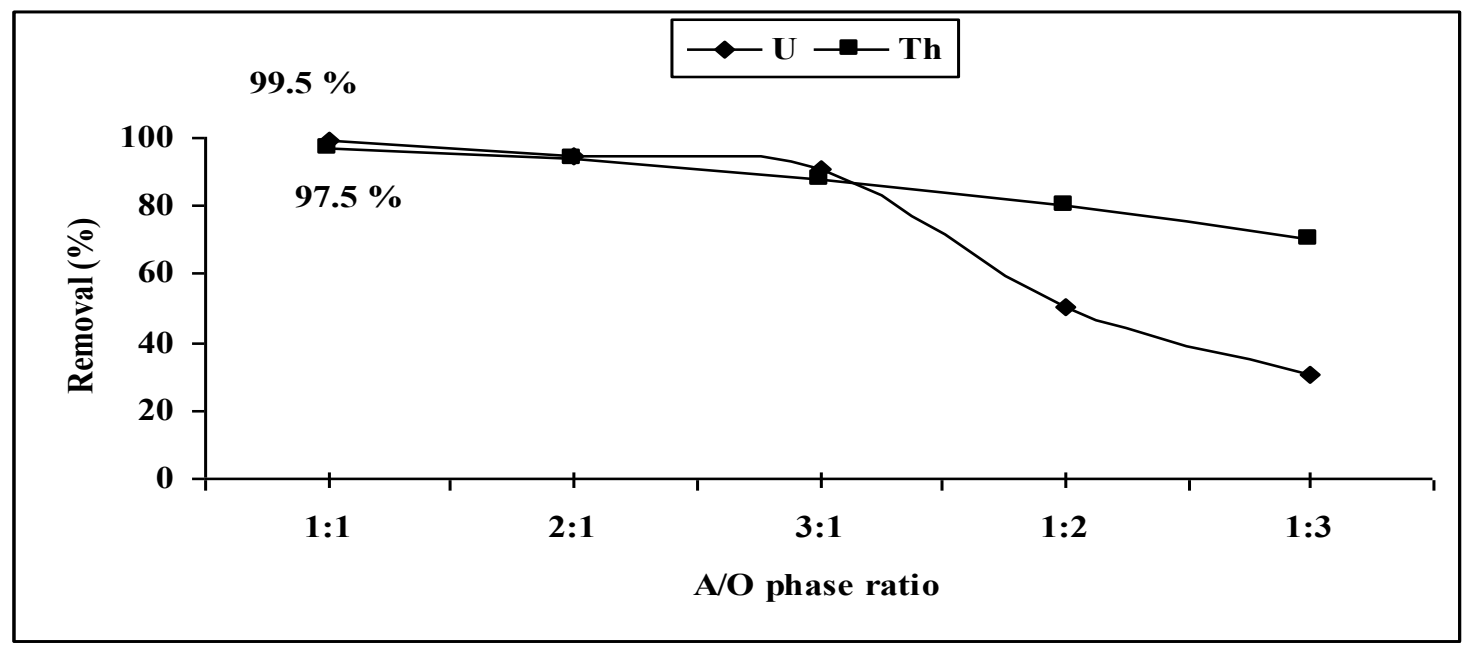

Removal conditions for uranium:

Uranium concentration : $100 \mathrm{ppb}$,

TOA dissolved in Kerosene, $0.02 \mathrm{M} \mathrm{TOA}$, ambient room temperature and shaking time:5 min.

Removal conditions for thorium :

Thorium concentration : $90 \mathrm{ppb}$,

TOA dissolved in Kerosene, $0.04 \mathrm{M} \mathrm{TOA}$, ambient room temperature and shaking time:5 min.

Fig.(4): Effect of $\mathrm{A} / \mathrm{O}$ phase ratio on uranium and thorium removal (\%). 


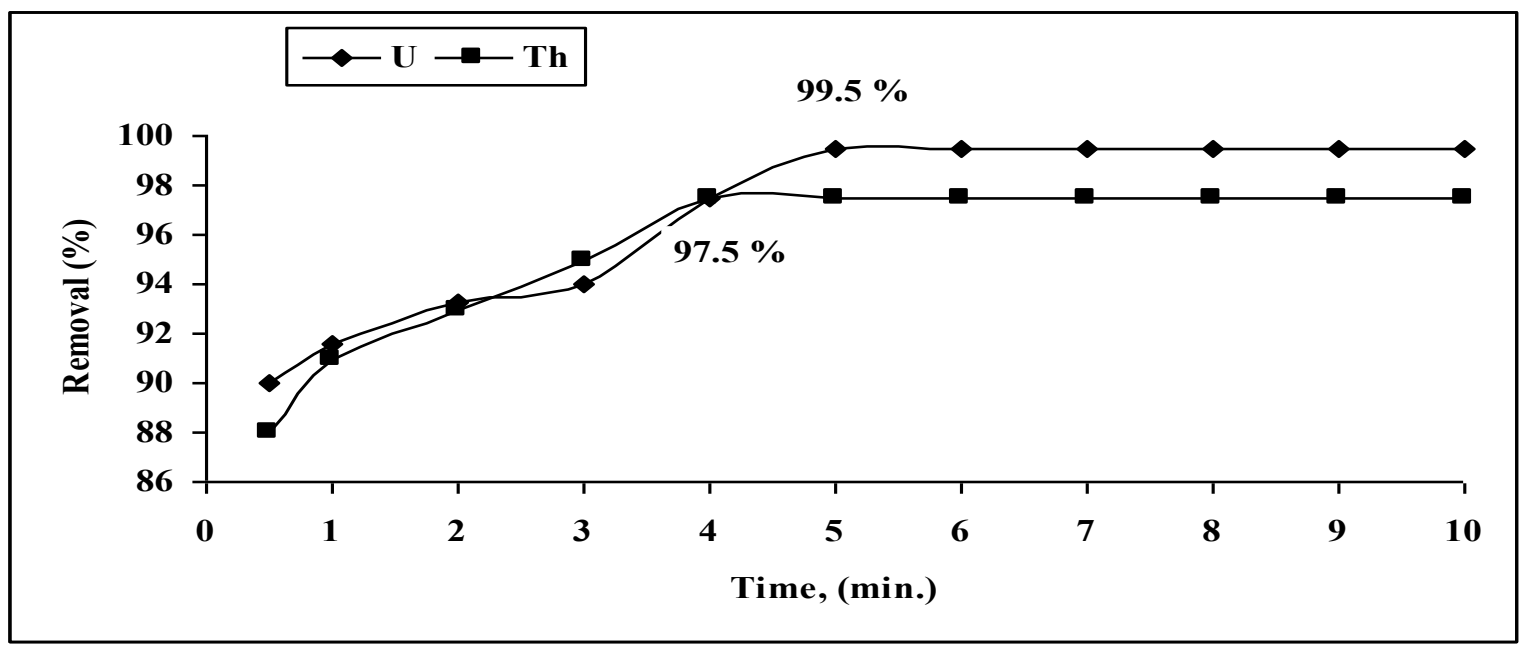

Removal conditions for uranium:

Uranium concentration : $100 \mathrm{ppb}$,

TOA dissolved in Kerosene, $0.02 \mathrm{M} \mathrm{TOA}$, ambient room temperature and A/O :1/1.

Removal conditions for thorium :

Thorium concentration : $90 \mathrm{ppb}$,

TOA dissolved in Kerosene, $0.04 \mathrm{M} \mathrm{TOA}$, ambient room temperature and A/O :1/1.

Fig.(5): Effect of shaking time on uranium and thorium removal (\%).

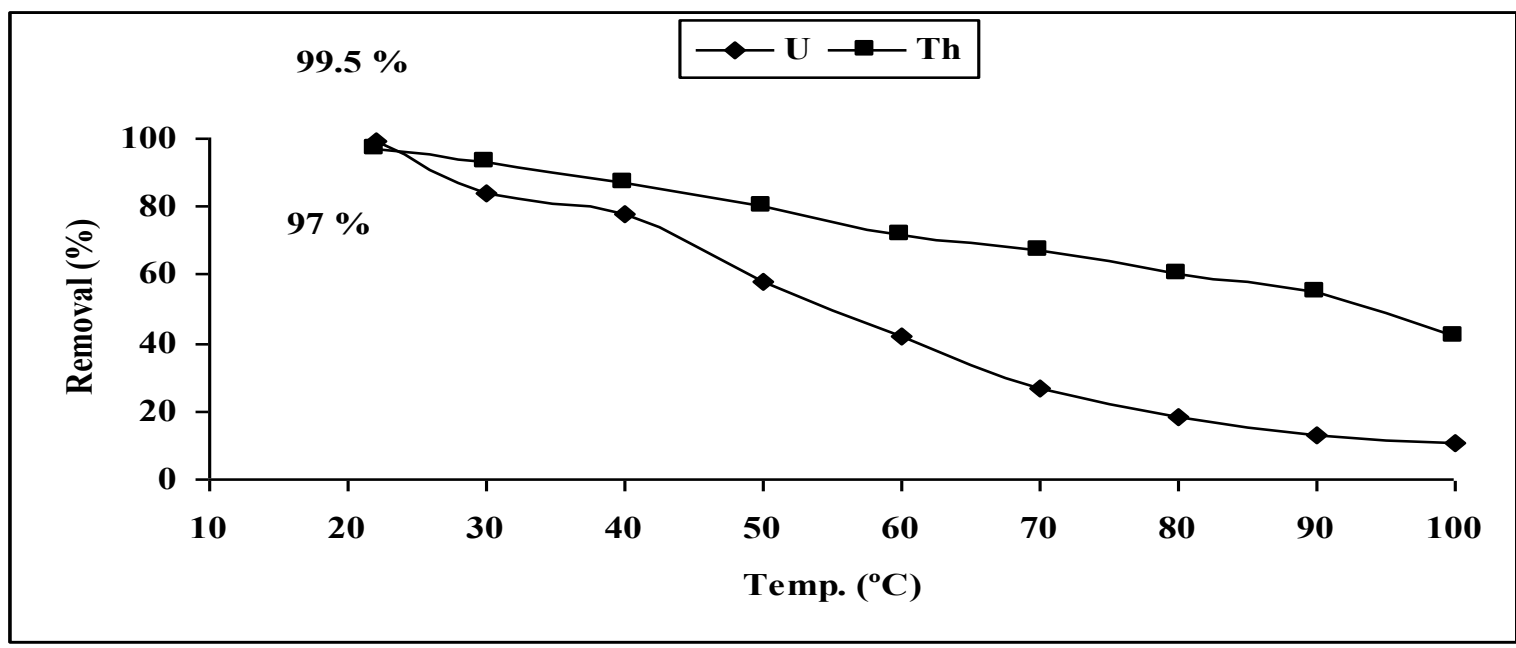

Removal conditions for uranium:

Uranium concentration : $100 \mathrm{ppb}$,

TOA dissolved in Kerosene, $0.02 \mathrm{M} \mathrm{TOA}$, A/O :1/1, ambient room temperature and shaking time:5 min. Removal conditions for thorium :

Thorium concentration : $90 \mathrm{ppb}$,

TOA dissolved in Kerosene, $0.04 \mathrm{M} \mathrm{TOA}$, A/O :1/1, ambient room temperature andshaking time:4 min.

Fig.(6): Effect of temperature on uranium and thorium removal (\%). 


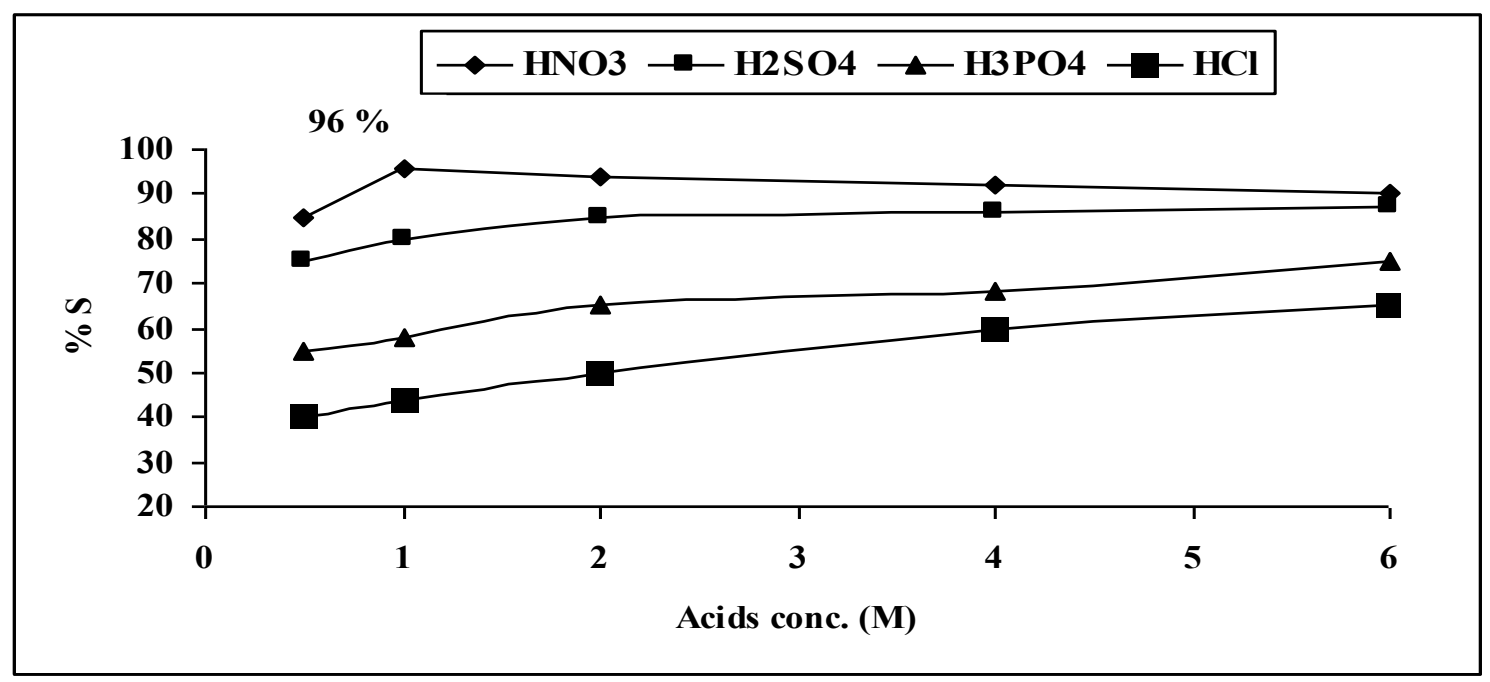

Removal conditions for uranium

Uranium concentration : $100 \mathrm{pp}$,

TOA dissolved in Kerosene, $0.02 \mathrm{MTOA}, A / O: 1 / 1$, ambient room temperature and shaking time 5 min. Fig.(7): Effect of different stripping agents on stripping process of $U$ from TOA.

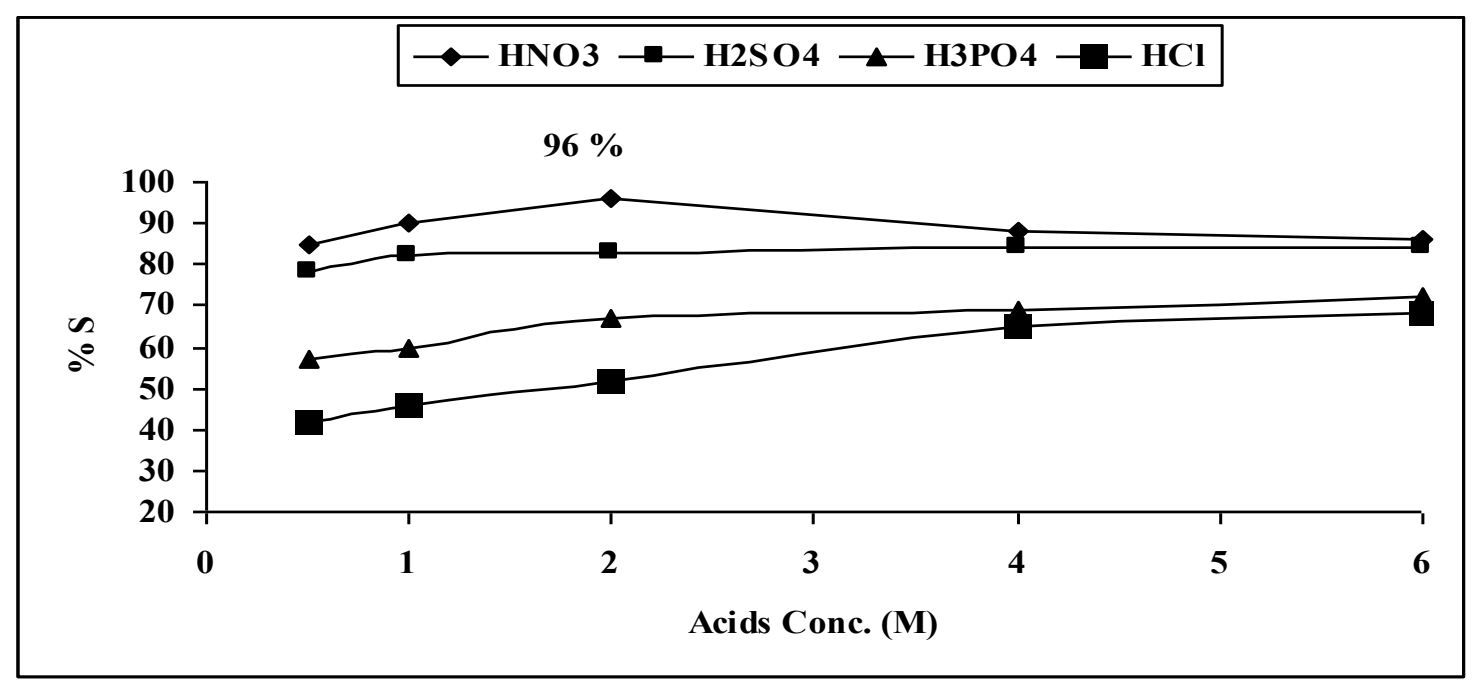

Removal conditions for thorium:

Thorium concentration : $90 \mathrm{ppb}$,

TOA dissolved in Kerosene, $0.04 \mathrm{M} \mathrm{TOA}, \mathrm{A} / \mathrm{O}: 1 / 1$, ambient room temperature and shaking time 4min. Fig.(8): Effect of different stripping agents on stripping process of Th from TOA. 


\section{List of Tables}

Table (1): Location of ten flood water samples of the Abu Rusheid area, south Eastern Desert,

\begin{tabular}{|c|c|c|c|}
\hline \multirow[t]{2}{*}{ Area } & \multirow[t]{2}{*}{ Sample No. } & \multicolumn{2}{|c|}{ Location } \\
\hline & & Latitude & Longitude \\
\hline \multirow{10}{*}{ 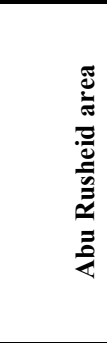 } & 1 & $24^{\circ} 37^{\prime} 37^{\prime \prime}$ & $34^{\circ} 46^{\prime} 05^{\prime \prime}$ \\
\hline & 2 & $24^{\circ} 37^{\prime} 49^{\prime \prime}$ & $34^{\circ} 46^{\prime} 15^{\prime \prime}$ \\
\hline & 3 & $24^{\circ} 37^{\prime} 50^{\prime \prime}$ & $34^{\circ} 46^{\prime} 13^{\prime \prime}$ \\
\hline & 4 & $24^{\circ} 37^{\prime} 50^{\prime \prime}$ & $34^{\circ} 46^{\prime} 08^{\prime \prime}$ \\
\hline & 5 & $24^{\circ} 37^{\prime} 51^{\prime \prime}$ & $34^{\circ} 46^{\prime} 05^{\prime \prime}$ \\
\hline & 6 & $24^{\circ} 37^{\prime} 51^{\prime \prime}$ & $34^{\circ} 46^{\prime} 03^{\prime \prime}$ \\
\hline & 7 & $24^{\circ} 37^{\prime} 35^{\prime \prime}$ & $34^{\circ} 46^{\prime} 05^{\prime \prime}$ \\
\hline & 8 & $24^{\circ} 37^{\prime} 38^{\prime \prime}$ & $34^{\circ} 46^{\prime} 02^{\prime \prime}$ \\
\hline & 9 & $24^{\circ} 37^{\prime} 38^{\prime \prime}$ & $34^{\circ} 46^{\prime} 03^{\prime \prime}$ \\
\hline & 10 & $24^{\circ} 37^{\prime} 38^{\prime \prime}$ & $3446^{\prime} 06^{\prime \prime}$ \\
\hline
\end{tabular}

Table (2): pH and T.D.S of flooding water samples, Abu Rusheid area, south Eastern Desert, Egypt.

\begin{tabular}{|c|c|c|c|}
\hline Sample No. & $\mathbf{p H}$ & T.D.S (ppm) & Rock types \\
\hline $\mathbf{1}$ & $\mathbf{8 . 1}$ & 940 & \\
\hline $\mathbf{2}$ & 7.8 & 1160 & \\
\hline $\mathbf{3}$ & 7.2 & 1280 & Cataclastic \\
rocks \\
\hline $\mathbf{5}$ & 7.5 & 440 & \\
\hline $\mathbf{6}$ & 7.6 & 600 & \\
\hline $\mathbf{7}$ & 7.4 & 600 & \\
\hline $\mathbf{8}$ & $\mathbf{7 . 1}$ & $\mathbf{1 4 6 0}$ & \\
\hline $\mathbf{1 0}$ & 7.5 & $\mathbf{3 8 0}$ & \\
\hline
\end{tabular}

Table (3): Uranium determination, removal using TOA and leaching \% of the studied area.

\begin{tabular}{|c|c|c|c|c|}
\hline Sample No. & $\begin{array}{c}\text { U (ppb) } \\
\text { determination }\end{array}$ & $\begin{array}{c}\mathbf{U} \text { (ppb) } \\
\text { removal using (TOA) }\end{array}$ & $\begin{array}{c}\text { eU* } \\
\text { (ppm) }\end{array}$ & Leaching (\%) \\
\hline $\mathbf{1}$ & $\mathbf{1 0 1 2}$ & $\mathbf{1 0 0 6 . 9 4}$ & 176 & 0.575 \\
\hline $\mathbf{2}$ & 370 & 368.2 & 307 & 0.121 \\
\hline $\mathbf{3}$ & 296 & 294.5 & 303 & 0.098 \\
\hline $\mathbf{4}$ & 296 & 294.5 & 221 & 0.134 \\
\hline $\mathbf{5}$ & 568 & 565.2 & 507 & 0.112 \\
\hline $\mathbf{6}$ & 592 & 589.0 & $\mathbf{6 6}$ & $\mathbf{0 . 9 0}$ \\
\hline $\mathbf{7}$ & 938 & 933.0 & 137 & 0.39 \\
\hline $\mathbf{8}$ & 345 & 343.3 & 88 & 0.39 \\
\hline $\mathbf{9}$ & 419 & 416.9 & 130 & 0.32 \\
\hline $\mathbf{1 0}$ & $\mathbf{1 7 2}$ & $\mathbf{1 7 1 . 0}$ & $\mathbf{5 4 1}$ & $\mathbf{0 . 0 3 2}$ \\
\hline
\end{tabular}

Removal conditions:

Uranium concentration : $100 \mathrm{ppb}, \mathrm{TOA}$ dissolved in Kerosene, $0.02 \mathrm{M} \mathrm{TOA,}$

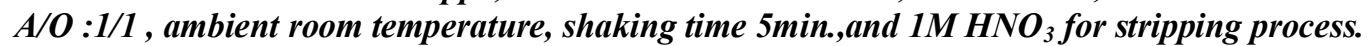

* eU(ppm) was measured in the field using gamma ray multi channel radiation detector 
Table (4): Thorium determination, removal using TOA and leaching \%.

\begin{tabular}{|c|c|c|c|c|}
\hline Sample No. & $\begin{array}{c}\text { Th (ppb) } \\
\text { determination }\end{array}$ & $\begin{array}{c}\text { Th (ppb) } \\
\text { removal using (TOA) }\end{array}$ & $\begin{array}{c}\text { eTh* } \\
\text { (ppm) }\end{array}$ \\
\hline $\mathbf{1}$ & $\mathbf{5 2 4}$ & $\mathbf{5 1 6}$ & $\mathbf{1 0 8 6}$ & 0.048 \\
\hline $\mathbf{2}$ & 122 & 119 & 310 & 0.039 \\
\hline $\mathbf{3}$ & $\mathbf{9 8}$ & $\mathbf{9 6}$ & 347 & 0.028 \\
\hline $\mathbf{4}$ & 183 & 178 & 304 & 0.060 \\
\hline $\mathbf{5}$ & 476 & 464 & $\mathbf{1 3 3}$ & $\mathbf{0 . 3 6}$ \\
\hline $\mathbf{6}$ & 122 & 119 & 939 & 0.031 \\
\hline $\mathbf{7}$ & 293 & 286 & 578 & 0.031 \\
\hline $\mathbf{8}$ & 207 & 202 & 834 & 0.036 \\
\hline $\mathbf{9}$ & 134 & 131 & 421 & $\mathbf{0 . 0 1 6}$ \\
\hline $\mathbf{1 0}$ & 402 & 395 & 0.095 \\
\hline
\end{tabular}

Removal conditions

Thorium concentration : $90 \mathrm{ppb}$, TOA dissolved in Kerosene, $0.04 \mathrm{M}$ TOA,

A/O :1/1 ambient room temperature, shaking time 4min. and $2 \mathrm{M} \mathrm{HNO}_{3}$ for stripping process.

* eTh(ppm) was measured in the field using gamma ray multi channel radiation detector

\section{Conclusion}

Ten flood water samples were collected from Abu Rusheid area, south Eastern Desert of Egypt. The salinity ranges between 380 and $1460 \mathrm{ppm}$. The water alkalinity of the studied samples ranges between 7.1 and 8.1 , indicating slightly basic media.

The removal of U (VI) and Th (IV) from flood water samples were studied using (TOA) dissolved in different diluents. The parameters affecting the removal and stripping of $U$ and Th include type of diluents, TOA concentrations, shaking time, temperature, $\mathrm{A} / \mathrm{O}$ ratio and stripping agents. The factors studied were followed by application of the suitable removal system to remove $\mathrm{U}$ and Th from flood water samples, on Abu Rusheid cataclastic rocks, south Eastern Desert, Egypt.

It was found that the best removal / stripping conditions for uranium were; $0.02 \mathrm{M}$ TOA dissolved in kerosene, 5 min. of shaking time at ambient room temperature, $\mathrm{A} / \mathrm{O} 1: 1$ and $1 \mathrm{M} \mathrm{HNO}_{3}$ acid for stripping of uranium. Under these conditions more than $99 \%$ of uranium is removed from the flood water samples. On the other hand, for thorium removal system the best conditions are; 0.04M TOA dissolved in kerosene, 4 min. shaking time at ambient room temperature, $\mathrm{A} / \mathrm{O} 1: 1$, and $2 \mathrm{M} \mathrm{HNO}_{3}$ acid as stripping agent. For this system, more than $97 \%$ of thorium is removed from the flood water samples.

The dissolution and leaching (\%) of uranium in flood water samples after one month from the falling of flood in the Abu Rusheid area are ranging between 0.032 and $0.9 \%$. Meanwhile, the leaching (\%) of thorium in flood water samples are ranging between 0.016 and $0.36 \%$.

Abu Rusheid area is located in a Wadi El Gemal national park and led the Red Sea. Live by people and animals use water either from wells or floods. After chemical treatment of the flood water was observed that the remaining elements of the uranium and thorium are very few. We recommend not to use those waters from flooding which contain a small concentration of uranium.

\section{Acknowledgements}

The authors wish to thank Prof. Dr. Mohamed El-Ahmadi Ibrahim, professor of Field Geology and Prof. Dr. Sofia Yahia Afifi, professor of Geochemistry, Nuclear Materials Authority, (NMA) for their help and fruitful discussions.

\section{References}

[1]. M. E. Ibrahim, K. Watanabe, G.M. Saleh and W. S. Ibrahim, Abu Rusheid lamprophyre dykes, South Eastern Desert, Egypt: As physical-chemical traps for REEs, Zn, Y, U, Cu, W and Ag, J.Geology and mining, 3 (3), 2013, xxx-xxx.

[2]. X. Lin, Flash floods in arid and semi-arid zones, IHP-V Technical Documents in Hydrology. no. $23,1999$.

[3]. K. Smith, and R. Ward, Floods - physical processes and human impacts, John Wiley \& Sons Ltd., Chichester, UK, 1998.

[4]. J.Broadman, L. Ligneau, A.P.J. De Roo and K.Vandaele, Flooding of property by runoff from agricultural land in northwestern Europe, J. Geomorphology, 10, 1994, 183-196.

[5]. M.El Bastawesy, K.White and A.Nasr, Integration of remote sensing and GIS for modelling flash floods in Wadi Hudain catchment, Egypt, J.Hydrol. Process, 23, 2009, 1359-1368.

[6]. B.E.Montz and E.Gruntfest, Flash flood mitigation: recommendations for research and applications, J.Environ. Hazard, 4, 2002, $15-22$. 
[7]. I. Abu El magd, E. Hermas, and M. El Bastawesy, GIS- modeling of the spatial varability of flash flood hazard in Abu Dabbab catchment, Red Sea Region, Egypt, The Egyptian journal of Remote Sensing and space Sciences, 13, 2010, 81-88.

[8]. M. Sultan, N. C. Sturchio, H. Gheith, Y.Abdel Hady and M.El Anbeawy, Chemical and isotopic constraints on the origin of Wadi El Tarfa ground water, Eastern Desert, Egypt, J.Ground water, 38, 2000, 743-751.

[9]. H. Gheith and M. Sultan, Construction of a hydrologic model for estimating wadi runoff an ld ground water recharge in the Eastern Desert, Egypt, J. Hydrology, 263, 2002, 36-55.

[10]. M. A. Sonbol, Sustainable systems of water harvesting in Arid Regions, A case Study: Sinai Peninsula-Egypt, Water Resources Res. Inst. National Water Res. Center, Cairo, Egypt, $2^{\text {nd }}$ International Conf. on Water Resources and Arid Environmental, 2006.

[11]. S. S. Hassan, Impact of flash floods on the Hydrological aquifer System at Delta Wadi El-Arish (North Sinai); Water Resources Research Institute (WRRI), (NWRC), $15^{\text {th }}$ International Water Technology Conference, Alexandria, Egypt ,2011.

[12]. M. S. El Sammany, Forecasting of flash floods over Wadi Watir - Sinai Peninsula using Weather Research and Forecasting (WRF) model, water Resources Research Institute, National Water Research Center, Egypt, Nile Basin Water Science and Engineering, $3(2), 2010,88-95$.

[13]. D. H. Pilgrim, T. G.Chapman, and D. G.Doran, Problems of rainfall-runoff modelling in arid and semiarid regions, J.Hydrol. Sci., 33, 1988, 379-400.

[14]. H. Gheith and M.Sultan, Construction of a hydrologic model for estimating Wadi runoff and groundwater recharge in the Eastern Desert, Egypt, J. Hydrol., 263, 2002, 36-55.

[15]. G. M. Foody, E. M.Ghoneim and N. W. Arnell, Predicting locations sensitive to flash flooding in an arid environment, J. Hydrol., 292, 2004, 48-58 .

[16]. E. Morin, D. C. Goodrich, R. A Maddox, X. G. Gao, H. V. Gupta and S. Sorooshian, Spatial patterns in thunderstorm rainfall events and their coupling with watershed hydrological response, Adv. Water Res., 29, 2006, 843-860.

[17]. E. Morin, Y. Jacoby, S. Navon and E. B.B. Halachmi, Towards flash-flood prediction in the dry Dead Sea region utilizing radar rainfall information, Adv. Water Res., 32, 2009, 1066-1076.

[18]. Y. Bahat, T. Grodek, J. Lekach and E.Morin, Rainfall-runoff modeling in a small hyper-arid catchment, J. Hydrol., 373, 2009,204 217.

[19]. J. Cools, P. Vanderkimpen, G. El Afandi, A. Abdelkhalek, S. Fockedey, M. El Sammany, G. Abdallah, M. El Bihery, W. Bauwens, and M. Huygens, An early warning system for flash floods in hyper-arid Egypt, J.Nat. Hazards Earth Syst. Sci., 12, 2012, 443-457.

[20]. C.A. Horton and J.C. White, Uranium extraction using trioctyl phosphine oxide (TOPO), J.Anal.Chem.,30, 1958, 1799-1805.

[21]. A.M. Kiwan and R.S. Amin, Diethylhexyl phosphoric acid as selective extractant for uranium and rare earth elements, J.Inorg.Nucl.Chem., 35, 1973, 3315-3319.

[22]. N.M. Sundaramrthi, G.S. Desai and V.M. Shinde, Spectrophotometric determination of trace and radioactive elements, J.Radioanal.Nucl.Chem.Letter,144, 1990, 439-446.

[23]. S. Yasumasa and K. Hideaki, Tributyl phosphine oxide diluted in toluene as organic phosphine group for the determination of uranium, J.Nucl. Sci. Techn. Tokyo. Japan, 20, 1983, 140-148.

[24]. A.A. Iseava, V.I. Golovano and I. Presnyakova, Spectrophotometric determination of uranium and extraction process, J.Radio. Chem., 19, 1977, 94-99.

[25]. B. Gupta, P. Malik and A. Deep, Separation and determination of uranium by cyanex-923, J.Radioanal. and Nucl. Chem., 251, 2002, 456-460.

[26]. Y. K. Agrawal and S. B. Vora, Separation of thorium and uranium by PBCHA, J.Microchim.Acta, 142, 2003, 261-266.

[27]. Y.K. Agrawal, G. Shab and S.B. Vora, Uranium extraction using different techniques, J.Radioanal. and Nucl. Chem., 270, 2006, 459-462.

[28]. N. S. Madane, G. H. Nikam, K. R. Mahanwar and B. S. Mohite, separation and extraction using Cyanex-272, J. Radioanal. and Nucl. Chem., 288, 2011, 290-299.

[29]. H.A.C. Mckay and R.J.W. Streeton, Separation of uranium from nuclear fuel using TBP, J.Inorg.Nucl.Chem., 27, 1965, $879-887$.

[30]. L.Shapiro and W.W. Brannock, Rapid Analysis of Silicates, Carbonates and Phosphate Rocks, U.S.Geol. Surv. Bulletin, 114, 1962, 56-63.

[31]. Z. Marczenko, Separation Spectrophotometric Determination of Elements, John Wiley and Sons, Harwood, New York, U.S.A., $1986,708 \mathrm{p}$.

[32]. A.A. Nemodruck and I.P. Glukhova, Spectrophotometric method for the determination of U (VI) using Arsenazo III, J.Anal.Chem., $18,1963,93-102$.

[33]. J. Borak, Z. Slovak and J. Fischer, Spectrophotometric method for the determination of uranium with Arsenazo III in the presence of interference elements, Talanta, 17, 1970, 215-218.

[34]. C.J. Kim, J. R. Kumar, J.S Kim, J.Y. Lee, and H.S. Yoon, Solvent extraction studies on uranium using amine based extractants and recovery from low grade ore leach liquors, J.Braz. Chem. Soc., 23, 2012, 1254-1264 .

[35]. S. N. Patkar, A. S. Burungale and R. J. Patil, Separation and liquid-liquid extraction of thorium (IV) as sulphate complex with synergistic mixture of n-octylaniline and trioctyl amine as an extractant, J.Chem., 2, 2009, 825-832.

[36]. T. Yamamoto and Y., Kanchiku, Spectrophotometric determination of uranium (VI) with Chlorophosphonazo III after tri-noctylamine extraction, J.Anal. Chem., 294 (4), 1979, 284-290.

[37]. J. Adam and R., Pribil, The extraction of uranium and its photometric determination with oxine and dibenzoylmethane. Analytical Laboratory, J. Heyrovsky Institute of Polarography, Czechoslovak Academy of Sciences, 37, 1972, 129-136. 